company follows a method of direct dealings with the customers. This method provides a good framework for customer satisfaction.

\section{SIGNIFICANCE OF THE STUDY}

Companies should try to satisfy their customers. Satisfied customers usually return to suppliers and buy more. They tell other customers about their experience with the suppliers and they may even pay a premium for the privilege of doing business with a trustworthy supplier. Statistics show that retaining a customer is only one/tenth of the cost of finding a new one. Therefore when a supplier gets a customer he should try to retain them.

The topic, 'Customer Satisfaction' is not only important but also relevant as it provides marketers and business owners with a metric that they can use to manage and improve their business.

The study is conducted among the customers who occupy a prominent position in Winplast Pvt. Ltd. So study of these customers and their satisfaction levels with the company are very important. Through this study, various aspects of customer satisfaction are measured.

$>$ The study is focused on selected customers of Winplast Pvt. Ltd. in the State of Kerala.

$>$ The study will help the company to know the weakness of the company in customer satisfaction.

$>$ The study helps to find the expectations of customers and helps the company to improvise their performance.

\section{RESEARCH METHODOLOGY}

This is a descriptive study. It is based on both primary and secondary data. The primary data required are collected using questionnaire. The secondary data required are collected from the published reports of the company of various years. As the study is on the customer satisfaction of customers of Winplast Pvt. Ltd., the total number of customers in the State of Kerala (78 in number) is considered as the universe for the purpose of the study. Out of the universe, 25 customers are selected as samples for the study. The said sample is selected on the basis of experience of customers. The customers selected are regular customers. The collected data is analyzed using mathematical tools like percentages. Graphs and diagrams are used to present the data in a better and understandable way.

\section{OBJECTIVES OF THE STUDY}

To study satisfaction levels of customers in Winplast Pvt. Ltd.

To identify the important components of customer satisfaction of customers of Winplast Pvt. Ltd.

To know the opinion of customers about the services and performance of Winplast Pvt. Ltd.

To propose suggestions for the improvement of customer satisfaction

\section{COMPANY PROFILE}

Winplast Polymer Products Private Ltd. is set up for manufacturing HDPE \& PP woven fabrics and sacks at Attoor, Thrissur District. It is strategically located as a limited company to meet the entire requirements of customers, by utilizing our maximum potential with existing infrastructural resources of the location. It aims at bringing together all the suitable resources available in the state and developing infrastructure to sustain industrial growth of the state.

Winplast Polymer Products Pvt. Ltd. is a major player in Kerala market as well as Southern states of the country. They offer tailor made packaging solutions, complete range of Poly Propylene (PP) and High Density Polyethylene (HDPE) bags and sacks as well as woven fabric. Currently they are supplying to all major bag conversion units throughout Kerala and Tamil Nadu and printed bags to major flour mills and cement companies. They are forecasted to export FIBC (jumbo bags).

High Density Polyethylene and Poly Propylene woven sacks have become a versatile commodity in the packaging industry introduced for the first time during the year 1969 thus replacing the Conventional jute bags to a large extent over the years. These sacks are immune to the effect of corrosion, decay, moisture, atmosphere, rats, rodents, moths and insects. Being superior in quality and economic as compared to the traditional jute material, these modern Sacks have gradually captured a large market. Saks made of PP/HDPE are laminated with LDPE inside, gives protection against moisture, air and the material packed cannot penetrate out of the sack and it is also suitable to keep the items required hygiene sensitiveness. 
International Journal of Trend in Scientific Research and Development (IJTSRD) ISSN: 2456-6470

The advanced machines and well-trained workforce consistent quality and competitive price every time at enables to execute all the bulk orders with perfection any part of the world.

and within the stipulated time frame with assurance of

\section{DATA ANALYSIS}

TABLE - 1: Showing the list of Product Range

\begin{tabular}{|c|}
\hline Products \\
\hline Woven bags/ sacks \\
\hline Leno/ Mesh bags \\
\hline Gusseted bags \\
\hline Natural bags \\
\hline Food grains and flour bags \\
\hline Liner bags \\
\hline Sand bag \\
\hline
\end{tabular}

TABLE - 2: Evaluation of the importance of certain product features that stimulate purchase of the product

\begin{tabular}{|l|c|c|c|c|c|c|c|c|c|c|}
\hline Characteristics & \multicolumn{2}{|l|}{$\begin{array}{l}\text { Extremely } \\
\text { important }\end{array}$} & \multicolumn{2}{l}{$\begin{array}{l}\text { Very } \\
\text { Important }\end{array}$} & \multicolumn{2}{l}{$\begin{array}{l}\text { Somewhat } \\
\text { Important }\end{array}$} & \multicolumn{2}{l|}{$\begin{array}{l}\text { Not very } \\
\text { Important }\end{array}$} & \multicolumn{2}{l|}{$\begin{array}{l}\text { Not at all } \\
\text { important }\end{array}$} \\
\hline & No & $\%$ & No & $\%$ & No & $\%$ & No & $\%$ & No & $\%$ \\
\hline Quality & 15 & 60 & 9 & 36 & 1 & 4 & 0 & 0 & 0 & 0 \\
\hline Price & 7 & 28 & 5 & 20 & 12 & 48 & 1 & 4 & 0 & 0 \\
\hline Durability & 6 & 24 & 17 & 68 & 2 & 8 & 0 & 0 & 0 & 0 \\
\hline $\begin{array}{l}\text { Purchase } \\
\text { experience }\end{array}$ & 7 & 28 & 11 & 44 & 4 & 16 & 3 & 12 & 0 & 0 \\
\hline $\begin{array}{l}\text { First use } \\
\text { experience }\end{array}$ & 11 & 44 & 7 & 28 & 6 & 24 & 1 & 4 & 0 & 0 \\
\hline $\begin{array}{l}\text { Usage } \\
\text { experience }\end{array}$ & 5 & 20 & 12 & 48 & 7 & 28 & 1 & 4 & 0 & 0 \\
\hline $\begin{array}{l}\text { After purchase } \\
\text { service }\end{array}$ & 7 & 28 & 7 & 28 & 6 & 24 & 5 & 20 & 0 & 0 \\
\hline
\end{tabular}

DIAGRAM - 1: Evaluation of the importance of certain product features that stimulate purchase of the product.

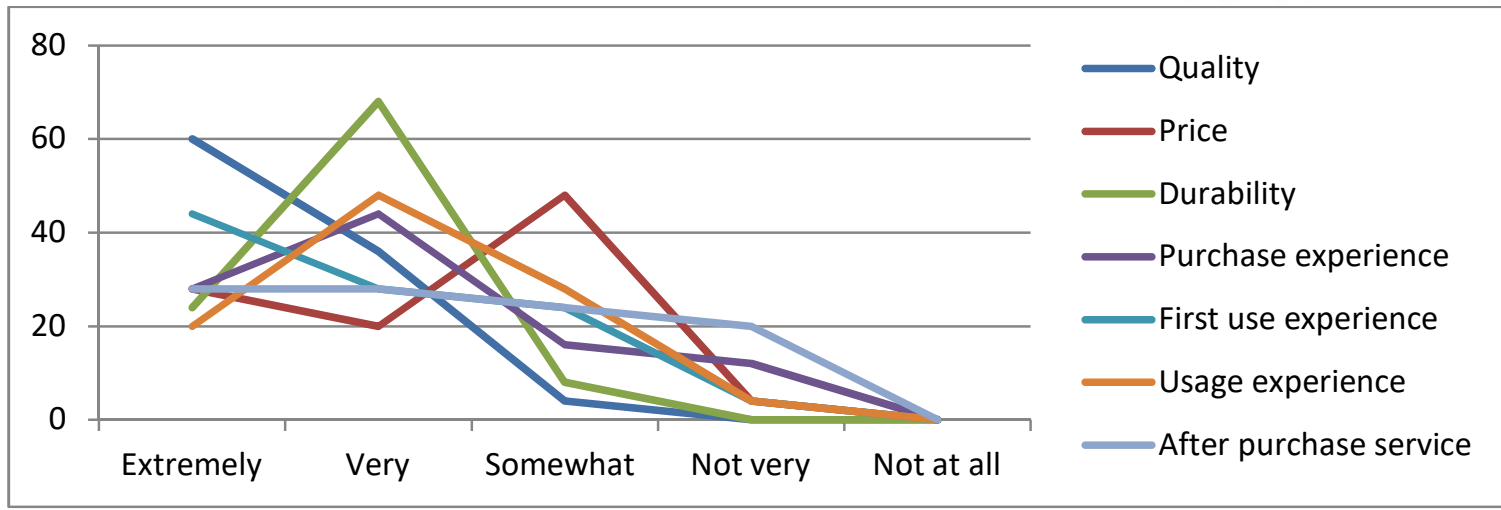




\section{Quality}

It is learned that $60 \%$ of the customers consider quality as extremely important and $36 \%$ of the customers consider it as very important. $4 \%$ of the customers consider quality as somewhat important. Quality is a key factor that consumers consider while purchasing the product. The company should produce good quality products to attain customer satisfaction and retain its customers.

\section{$>$ Price}

It is learned that $28 \%$ of the customers consider price as extremely important and $20 \%$ of the customers consider it as very important. $48 \%$ of the customers consider price as somewhat important and $4 \%$ consider it as not very important. Price is a factor that consumers consider while purchasing the product but it is not an important factor that affects purchasing decision.

\section{Durability}

It is learned that $24 \%$ of the customers consider durability as extremely important and $68 \%$ of the customers consider it as very important. $8 \%$ of the customers consider price as somewhat important. Durability is a factor that consumers consider while purchasing the product but it is an important factor that affects purchasing decision.

\section{Purchase experience}

It is learned that $28 \%$ of the customers consider purchase experience as extremely important and $44 \%$ of the customers consider it as very important. $16 \%$ of the customers consider purchase experience as somewhat important and $12 \%$ consider it as not very important. Purchase experience is a factor that consumers consider while purchasing the product. From the analysis we can assume that it is a factor that affects purchasing decision of no prime importance.

\section{First use experience}

It is learned that $44 \%$ of the customers consider first use experience as extremely important and $28 \%$ of the customers consider it as very important. $24 \%$ of the customers consider first use experience as somewhat important and $4 \%$ consider it as not very important. First use experience is a factor that consumers consider while purchasing the product. From the analysis we can assume that it is a factor that affects purchasing decision of no prime importance.

\section{Usage experience}

It is learned that $20 \%$ of the customers consider usage experience as extremely important and $48 \%$ of the customers consider it as very important. $28 \%$ of the customers consider usage experience as somewhat important and $4 \%$ consider it as not very important. Usage experience is a factor that consumers consider while purchasing the product. From the analysis we can assume that it is a factor that affects purchasing decision of no prime importance.

\section{After purchase service}

It is learned that $28 \%$ of the customers consider customer service as extremely important and as very important. $24 \%$ of the customers consider customer service as somewhat important and $20 \%$ consider it as not very important. Customer service is a factor that consumers consider while purchasing the product. From the analysis we can see that customer service is considered important by more than half of the customers and less than half of the customers don't give much importance for it. Customer service requirements differ among different customers. 
TABLE - 3: Evaluating recent experience of customers with the product or service

\begin{tabular}{|l|c|c|c|c|c|c|c|c|c|c|}
\hline Characteristics & \multicolumn{3}{l}{$\begin{array}{l}\text { Strongly } \\
\text { agree }\end{array}$} & \multicolumn{2}{l}{$\begin{array}{l}\text { Somewhat } \\
\text { agree }\end{array}$} & \multicolumn{2}{l|}{$\begin{array}{l}\text { Neither agree } \\
\text { nor disagree }\end{array}$} & \multicolumn{2}{l|}{$\begin{array}{l}\text { Somewhat } \\
\text { disagree }\end{array}$} & \multicolumn{2}{l|}{$\begin{array}{l}\text { Strongly } \\
\text { disagree }\end{array}$} \\
\hline & No & $\%$ & No & $\%$ & No & $\%$ & No & $\%$ & No & $\%$ \\
\hline $\begin{array}{l}\text { Worth the } \\
\text { purchase price }\end{array}$ & 16 & 64 & 8 & 32 & 1 & 4 & 0 & 0 & 0 & 0 \\
\hline $\begin{array}{l}\text { Product/service } \\
\text { does what it } \\
\text { claims }\end{array}$ & 9 & 36 & 14 & 56 & 2 & 8 & 0 & 0 & 0 & 0 \\
\hline What I need & 13 & 52 & 6 & 24 & 6 & 24 & 0 & 0 & 0 & 0 \\
\hline Easy to use & 9 & 36 & 12 & 48 & 4 & 16 & 0 & 0 & 0 & 0 \\
\hline $\begin{array}{l}\text { Competitively } \\
\text { priced }\end{array}$ & 6 & 24 & 8 & 32 & 6 & 24 & 5 & 20 & 0 & 0 \\
\hline
\end{tabular}

DIAGRAM - 2: Evaluating recent experience of customers with the product or service

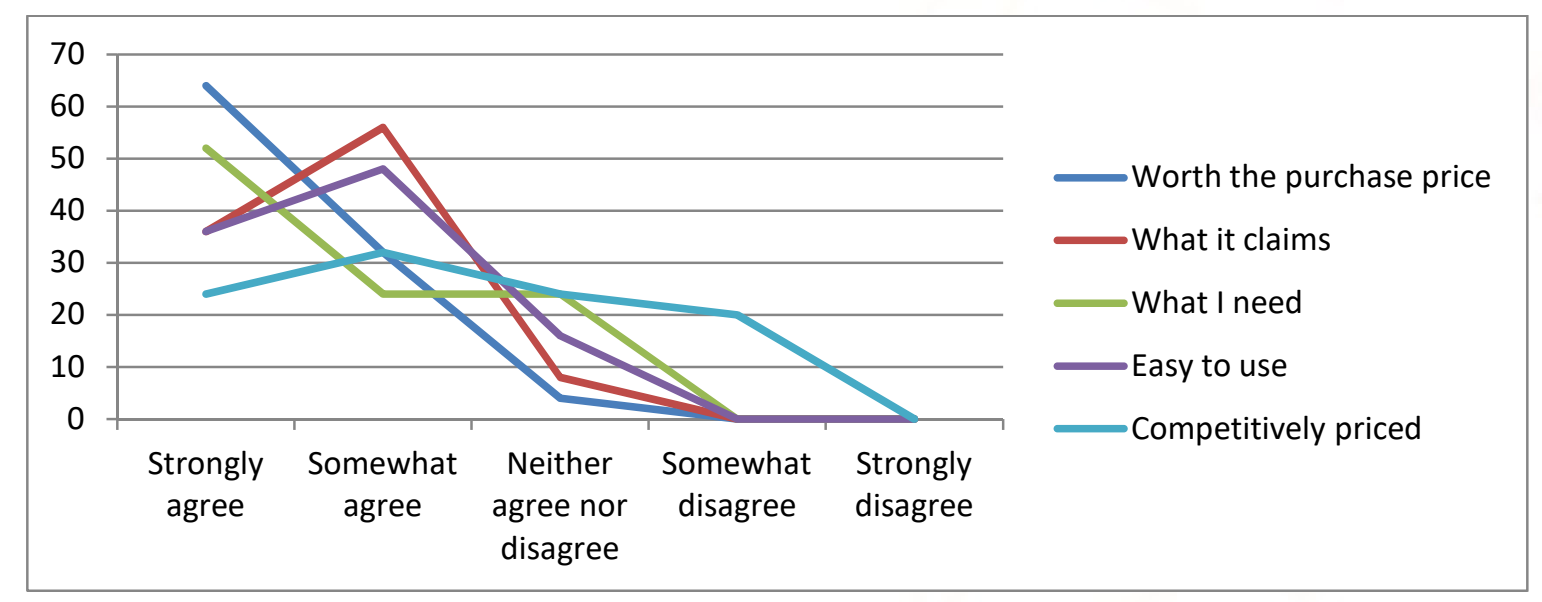

\section{$>$ Product/service was worth the purchase price}

It is learned that $64 \%$ of the customers strongly agree and $32 \%$ of the customers somewhat agree that product is worth the price. $8 \%$ of the customers neither agree nor disagree with that. Price worth of the product is a factor that consumers consider while purchasing the product. Almost all customers consider price worthiness of the product while purchasing the product from the company. The product should always be worth the price. Over priced products will discourage customers. Under priced products will bring loss to the company. Prices should be fixed accordingly so as to retain customers and earn profits.

\section{$>$ Product/service does what it claims}

It is learned that $36 \%$ of the customers strongly agree and $56 \%$ of the customers somewhat agree that product does what it claims. $8 \%$ of the customers neither agree nor disagree with that. The product should able to do what it claims or it will be useless to the customers discouraging them.

\section{Product/service does what I need}

It is learned that $52 \%$ of the customers strongly agree and $24 \%$ of the customers somewhat agree that product does what they need. $24 \%$ of the customers neither agree nor disagree with that. Utilities like time utility, place utility etc should be maintained so that the product would be useful to the customers and do what they need.

\section{Product/service is easy to use}

It is learned that $36 \%$ of the customers strongly agree and $48 \%$ of the customers somewhat agree that product 
International Journal of Trend in Scientific Research and Development (IJTSRD) ISSN: 2456-6470

is easy to use. $16 \%$ of the customers neither agree nor disagree with that. The product is rather easy to use. Only some customers find it a bit difficult to use. If the use of the product is complicated customers should be given proper instructions.

\section{Product/service is competitively priced}

It is learned that $24 \%$ of the customers strongly agree and $48 \%$ of the customers somewhat agree that product is easy to use. $16 \%$ of the customers neither agree nor disagree with that. Pricing of product is a major management decision. The company should consider price fixed by the competitors while making the pricing decision. If the price of the product is more than what our competitors has set it would pave way for derailing of customers.

TABLE-4: Evaluation of overall rating of customer service

\begin{tabular}{|c|c|c|c|c|c|c|c|c|c|c|}
\hline \multirow[t]{2}{*}{ Characteristics } & \multicolumn{2}{|c|}{$\begin{array}{l}\text { Very } \\
\text { satisfied }\end{array}$} & \multicolumn{2}{|c|}{$\begin{array}{l}\text { Somewhat } \\
\text { satisfied }\end{array}$} & \multicolumn{2}{|c|}{$\begin{array}{l}\text { Neither } \\
\text { satisfied nor } \\
\text { dissatisfied }\end{array}$} & \multicolumn{2}{|c|}{$\begin{array}{l}\text { Somewhat } \\
\text { dissatisfied }\end{array}$} & \multicolumn{2}{|c|}{$\begin{array}{l}\text { Very } \\
\text { dissatisfied }\end{array}$} \\
\hline & No & $\%$ & No & $\%$ & No & $\%$ & No & $\%$ & No & $\%$ \\
\hline Issue resolution & 7 & 28 & 11 & 44 & 7 & 28 & 0 & 0 & 0 & 0 \\
\hline Quality of advice & 6 & 24 & 15 & 60 & 4 & 16 & 0 & 0 & 0 & 0 \\
\hline $\begin{array}{l}\text { Promptness of } \\
\text { answering phone }\end{array}$ & 11 & 44 & 8 & 32 & 5 & 20 & 1 & 4 & 0 & 0 \\
\hline $\begin{array}{l}\text { Quality of issue } \\
\text { handling }\end{array}$ & 8 & 32 & 7 & 28 & 10 & 40 & 0 & 0 & 0 & 0 \\
\hline Professionalism & 11 & 44 & 8 & 32 & 4 & 16 & 2 & 4 & 0 & 0 \\
\hline $\begin{array}{l}\text { Ease of contacting } \\
\text { Customer Service }\end{array}$ & 7 & 28 & 12 & 36 & 4 & 16 & 2 & 4 & 0 & 0 \\
\hline $\begin{array}{l}\text { Helpfulness of } \\
\text { Representative }\end{array}$ & 10 & 40 & 7 & 28 & 5 & 20 & 3 & 12 & 0 & 0 \\
\hline $\begin{array}{l}\text { Promptness of email } \\
\text { response }\end{array}$ & 11 & 44 & 7 & 28 & 5 & 20 & 2 & 8 & 0 & 0 \\
\hline
\end{tabular}

DIAGRAM - 3: Evaluation of overall rating of customer service

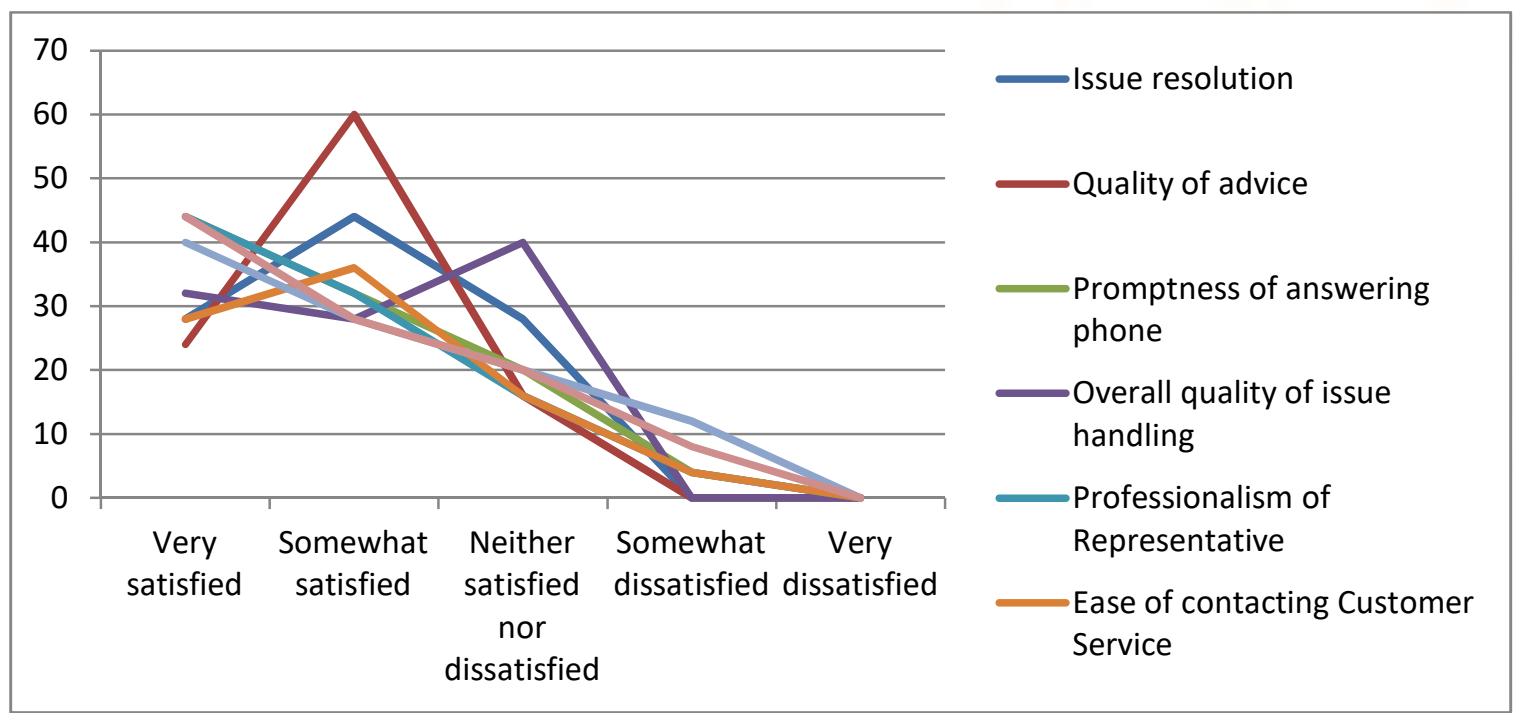




\section{Issue resolution}

It is learned that $28 \%$ of the customers are very satisfied and $44 \%$ of the customers are somewhat satisfied with the issue resolution provided by the company. $28 \%$ of the customers are neither satisfied nor dissatisfied. Although most of the customers are okay with issue resolution a minor part is not. Company should issue adequate measures for issue resolution.

\section{$>$ Quality of advice}

It is learned that $28 \%$ of the customers are very satisfied and $44 \%$ of the customers are somewhat satisfied with the quality of service provided by the company. $28 \%$ of the customers are neither satisfied nor dissatisfied. If the quality of customer service is good enough it will help to attain customer satisfaction.

\section{$>\quad$ Promptness of answering phone}

It is learned that $44 \%$ of the customers are very satisfied and $32 \%$ of the customers are somewhat satisfied with the promptness of answering the phone by the company. $20 \%$ of the customers are neither satisfied nor dissatisfied. $4 \%$ of the customers are somewhat dissatisfied. Customers may be busy people and the company should see their time is not wasted by attending their calls by paying due attention.

\section{$>$ Overall quality of issue handling}

It is learned that $32 \%$ of the customers are very satisfied and $40 \%$ of the customers are somewhat satisfied with the issue holding of the company. $28 \%$ of the customers are neither satisfied nor dissatisfied. Paying attention to handling issues helps company to retain customers and create healthy relationship with the customers.

\section{$>$ Professionalism of Representative}

It is learned that $44 \%$ of the customers are very satisfied and $32 \%$ of the customers are somewhat satisfied with the professionalism of representative. $16 \%$ of the customers are neither satisfied nor dissatisfied. $8 \%$ of the customers are somewhat dissatisfied. The customer representative must be a professional so that he can maintain a good relation between the customers and the company.

\section{$>$ Ease of contacting Customer Service}

It is learned that $28 \%$ of the customers are very satisfied and $48 \%$ of the customers are somewhat satisfied with the ease of contacting customer service. $16 \%$ of the customers are neither satisfied nor dissatisfied. $8 \%$ of the customers are somewhat dissatisfied. Most of the customers show a positive opinion. The customer service of the company should be at the beck and call of the customers at all times.

\section{$>$ Helpfulness of Representative}

It is learned that $40 \%$ of the customers are very satisfied and $28 \%$ of the customers are somewhat satisfied with the helpfulness of representative. $20 \%$ of the customers are neither satisfied nor dissatisfied. $12 \%$ of the customers are somewhat dissatisfied. The customer representative should be helpful to the customers. This will create a friendly environment for the customers thus helping in attaining customer satisfaction

\section{$>$ Promptness of email response}

It is learned that $44 \%$ of the customers are very satisfied and $28 \%$ of the customers are somewhat satisfied with the promptness of email response. $20 \%$ of the customers are neither satisfied nor dissatisfied. $8 \%$ of the customers are somewhat dissatisfied. It is the era of computers and internet. Companies should be update with their emails. Customer emails should be attended readily. 
International Journal of Trend in Scientific Research and Development (IJTSRD) ISSN: 2456-6470

TABLE - 5: Evaluating performance of the customer representative

\begin{tabular}{|l|c|c|c|c|c|c|c|c|c|c|}
\hline \multicolumn{1}{|c|}{ Characteristics } & $\begin{array}{c}\text { Strongly } \\
\text { agree }\end{array}$ & \multicolumn{3}{c|}{ Agree } & \multicolumn{2}{c|}{ Neutral } & \multicolumn{2}{c|}{ Disagree } & \multicolumn{2}{c|}{$\begin{array}{c}\text { Strongly } \\
\text { disagree }\end{array}$} \\
\hline & No & $\%$ & No & $\%$ & No & $\%$ & No & $\%$ & No & $\%$ \\
\hline Knowledgeable & 9 & 36 & 15 & 60 & 1 & 4 & 0 & 0 & 0 & 0 \\
\hline Patient & 7 & 28 & 10 & 40 & 7 & 28 & 1 & 4 & 0 & 0 \\
\hline Enthusiastic & 6 & 24 & 8 & 32 & 10 & 40 & 1 & 4 & 0 & 0 \\
\hline $\begin{array}{l}\text { Listened } \\
\text { carefully }\end{array}$ & 8 & 32 & 10 & 40 & 6 & 24 & 1 & 4 & 0 & 0 \\
\hline Friendly & 7 & 28 & 11 & 44 & 8 & 32 & 0 & 0 & 0 & 0 \\
\hline Responsive & 14 & 56 & 7 & 28 & 3 & 12 & 1 & 4 & 0 & 0 \\
\hline Courteous & 11 & 44 & 9 & 36 & 4 & 16 & 1 & 4 & 0 & 0 \\
\hline
\end{tabular}

DIAGRAM - 4: Evaluating performance of the customer representative

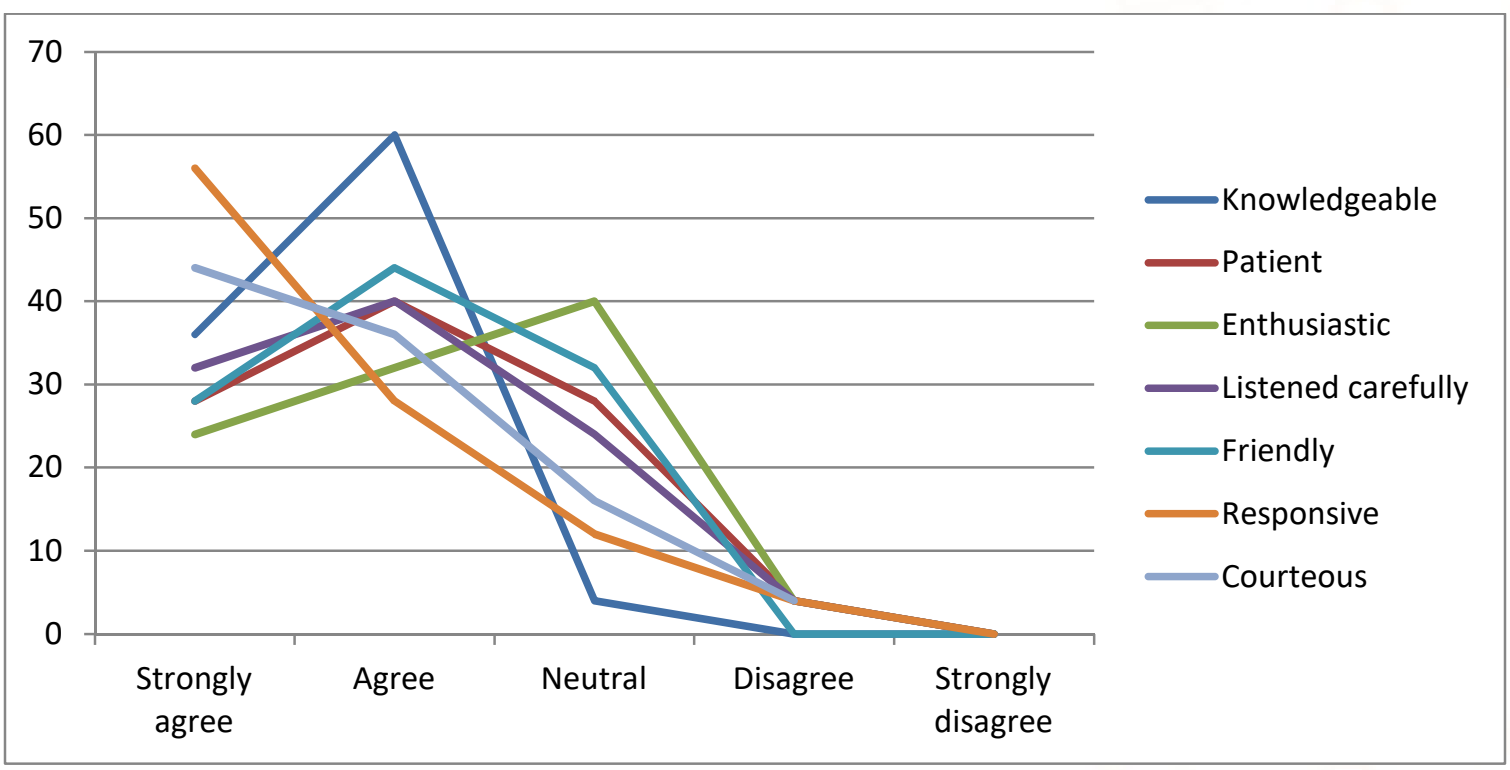

\section{$>$ Knowledgeable}

It is learned that $36 \%$ of the customers strongly agree and $60 \%$ of the customers agree that customer representative is patient. $4 \%$ of the customers neither agree nor disagree with that. Customer representatives are usuallys professionals. They are polymaths in their field of job. This enables them to help customers in a much better and efficient way.

\section{Patient}

It is learned that $28 \%$ of the customers strongly agree and $40 \%$ of the customers agree that customer representative is patient. $28 \%$ of the customers neither agree nor disagree with that. $4 \%$ of the customers disagree with that. Customer representatives should be patient in any given situation. They should be able to handle any type of customers in any hectic or chaotic situation. Patience is a virtue that is to be mastered.

\section{Enthusiastic}

It is learned that $24 \%$ of the customers strongly agree and $32 \%$ of the customers agree that customer representative is enthusiastic. $40 \%$ of the customers neither agree nor disagree with that. $4 \%$ of the customers disagree with that. We can see that the customer representative needs to be more enthusiastic. Only an active representative will be a helpful representative when it comes to the customer's point of view. 


\section{Listened carefully}

It is learned that $32 \%$ of the customers strongly agree and $40 \%$ of the customers agree that customer representative listens carefully. $24 \%$ of the customers neither agree nor disagree with that. $4 \%$ of the customers disagree with that. A customer representative is the key link between customers and company. They have to listen and perceive the customers accurately. Only through good communication the customer relationship with the company will grow.

\section{Friendly}

It is learned that $28 \%$ of the customers strongly agree and $44 \%$ of the customers agree that customer representative is friendly. $32 \%$ of the customers neither agree nor disagree with that. Only a friendly customer representative can retain customers. The company customer representative is quite friendly.

\section{Responsive}

It is learned that $56 \%$ of the customers strongly agree and $28 \%$ of the customers agree that customer representative is responsive. $12 \%$ of the customers neither agree nor disagree with that. $4 \%$ of the customers disagree with that. A responsive representative is what customers require rather than an irresponsible one. Responsibility is an important factor he must possess.

\section{Courteous}

It is learned that $44 \%$ of the customers strongly agree and $36 \%$ of the customers agree that customer representative is responsive. $16 \%$ of the customers neither agree nor disagree with that. $4 \%$ of the customers disagree with that. A courteous person can impress the customers and get them on our side. A good customer representative can win the hearts of the customers and help to achieve customer satisfaction.

\section{FINDINGS}

While comparing the overall satisfaction rating of the company, it shows a somewhat satisfied rate when compared to the other degrees of satisfaction.

The products are highly recommended to external people due to the efficiency in the service rendered.

$>$ The features of the product attracted customers and stimulated in the purchase of the product.

$>$ While comparing quality, price, durability, purchase experience, first use experience, usage experience and customer service we can see a stable status in the services provided.

Maximum utilization of resources is achieved while producing products and providing services.

$>$ As the products are competitively priced it helps the management to foresee the uncertainties and risks in the business environment.

$>$ Purchase of product is seemed to be consistent in nature.

$>$ Overall customer service is found to be more likely by the customers.

$>$ The customer representative is courteous and friendly in nature according to the customers.

\section{SUGGESTIONS}

From the study it is seen that Winplast Polymer Products PVT. Ltd. is successful in creating customer satisfaction among the customers. Most of the customers are satisfied with the services provided. There are some factors that the company needs to give attention to in order to strengthen the relationship between the company and its customers.

The following are some suggestions for that will help the company to improve its performance in customer satisfaction: 
The firm has to keep up the pricing of the product by competitively pricing the product.

$>$ The firm has to maintain qualitative facts in issue handling.

$>$ The firm has to come up with better discount packages in order to attract and retain customers.

\section{CONCLUSION}

This research has revealed that customer satisfaction can be defined as an overall customer attitude towards a service provider or an emotional reaction to the difference between what customers anticipate and what they receive, regarding the fulfillment of some need, goal or desire. Customer satisfaction does have a positive effect on an organization's profitability. Satisfied customers form the foundation of any successful business as customer satisfaction leads to repurchase, brand loyalty and positive word of mouth.

By analyzing this project we can understand that Winplast Polymer Products PVT. Ltd. provides quality products to their customers. But they do not provide enough sales promotional activities like advertisement or other activities. If they provide these activities it will increase their sale.

\section{REFERENCES}

Books

1. Research \& Methodology : C. R. Kothari

2. Handbook of Customer Satisfaction and Loyalty Measurement: Book by Jim Alexander and Nigel Hill

3. Customer Satisfaction Evaluation: Methods for Measuring and Implementing Service Quality: Evangelos Grigoroudis, Yannis Siskos

4. Improving your measurement of customer satisfaction: Terry G. Vavra

\section{Websites}

1. http://www.businessdictionary.com/

2. https://www.investopedia.com/

3. http://blog.clientheartbeat.com/

4. https://www.b2binternational.com/ 